\title{
Conceptual foundations of the theory of road safety
}

\author{
Irina Ilina $^{1 *}$ \\ ${ }^{1}$ Penza state University of architecture and construction, Penza, Russia
}

\begin{abstract}
The analysis of the content of legislative, regulatory and technical sources regulating activities in the field of road safety in the Russian Federation is carried out. The federal target programs adopted for implementation in different years aimed at improving the state of road safety are studied. The object of the study is the theory of road safety. The theory is based on the principle of protecting the life and health of citizens enshrined in the Constitution of the Russian Federation. Several levels are considered from the point of view of the development, implementation and control of the effectiveness of measures to improve road safety. The result is obtained in the form of a single pyramid of the theory of road safety. The theory assumes the appearance of a significant factor in the assessment of the state of safety in transport processes. The presented concept allows you to predict the state of road safety.
\end{abstract}

In theoretical terms, the problem of ensuring road safety has been developed on the initiative of the international community since the end of the XIX century - since the first fatal road traffic accident. Until the end of the twentieth century, this problem continued to be solved largely thanks to the efforts of the United Nations Economic Commission for Europe. [1,2] The first work in the Russian Federation to ensure road safety dates back to the late 1970s.

The degree of protection of participants in the transport process from road accidents and their consequences is defined by the term "road safety".

In turn, the process of ensuring road safety consists of activities aimed at preventing the causes of road accidents, reducing the severity of their consequences. The wording of the above terms is fixed in the Federal Law of the Russian Federation "On Road Safety".

Currently, the system for preventing road accidents and injuries is based on the assessment of the effectiveness of the measures carried out, mainly in the engineering and technical direction (Fig. 1). Preventive work with the population has a differential approach and is presented in the form of measures aimed at individual categories of the population.

*Corresponding author: iie.1978@yandex.ru 


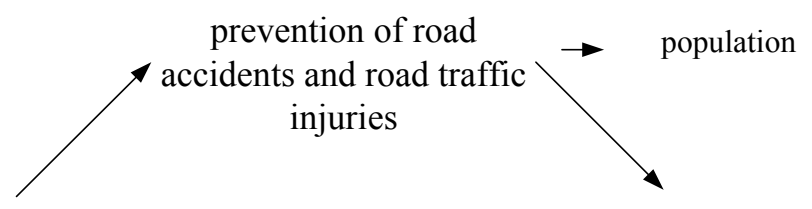

evaluation of the

effectiveness of

prevention of

measures


road accidents

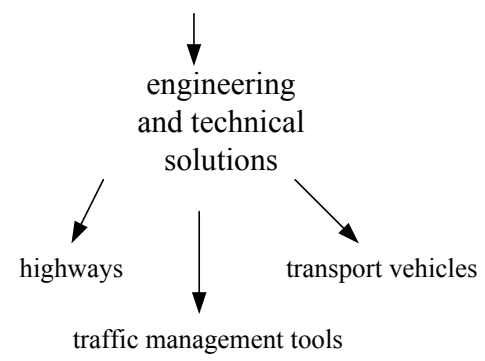

Fig. 1. Modern understanding of the road accident prevention system

Following a meeting of the State Council held on June 26, 2019, the President of the Russian Federation approved a list of instructions aimed at reducing the death rate and injuries of the population as a result of road accidents on highways, as well as improving the efficiency of the management system in the field of road safety. The development and approval of the state program of the Russian Federation for ensuring road safety for the period up to 2030 should cover measures aimed at strengthening administrative responsibility for violations of traffic rules and the inevitability of punishment, as well as improving programs for teaching children the skills of safe participation in road traffic. President Vladimir Putin noted that " The prevention of road accidents is a key task» [3]

The algorithm for forming the theory of road safety is based on the conceptual knowledge of its composition and structure. In the course of the research, materials devoted to the system analysis of road safety problems were studied. $[4,5,6]$

The analysis of the content of works devoted to the issue of improving road safety aimed at studying the influence of the driver, improving the capacity of roads, traffic management on the road network. [7, 8, 9]

For clarity, we will display the components of the theory of road safety in the form of a pyramid, the construction of which is based on the principle of "analysis - prevention provision - control - consequence".

The base of the pyramid theory of road safety will be the position of the Federal law "On road safety" - protection of life, health and property of citizens, protect their rights and legitimate interests, and also protection of the interests of society and state by preventing traffic accidents, reducing the severity of their impact. (fig. 2)

This provision is an axiom and is fixed in the normative act of the highest legal force the Constitution of the Russian Federation - it is the basis of other laws aimed at preserving human life and health.

Absolutely everyone is a road user. In accordance with the legislation of the Russian Federation, this is a driver, pedestrian, or passenger. However, the status of a person as a road user changes from pedestrian to driver or passenger at different times of the day. [10]

In addition, the individual administrative and legal status of a citizen changes throughout life, which implies the legal consolidation of the position of a citizen in society with a set of rights, guarantees, duties and responsibilities. There are three types of statuses. 
Thus, the "special" status includes orphans, the unemployed, refugees, students, veterans, the disabled, residents of territories with a special administrative regime, civil servants, persons who have committed offenses, etc. The" Individual " status specifies a citizen by gender, age, marital status. The "general" status applies to all citizens of the State and is enshrined in the Constitution. [11] Thus, it is obvious that the knowledge, skills and abilities of a person of different administrative and legal status differ significantly.

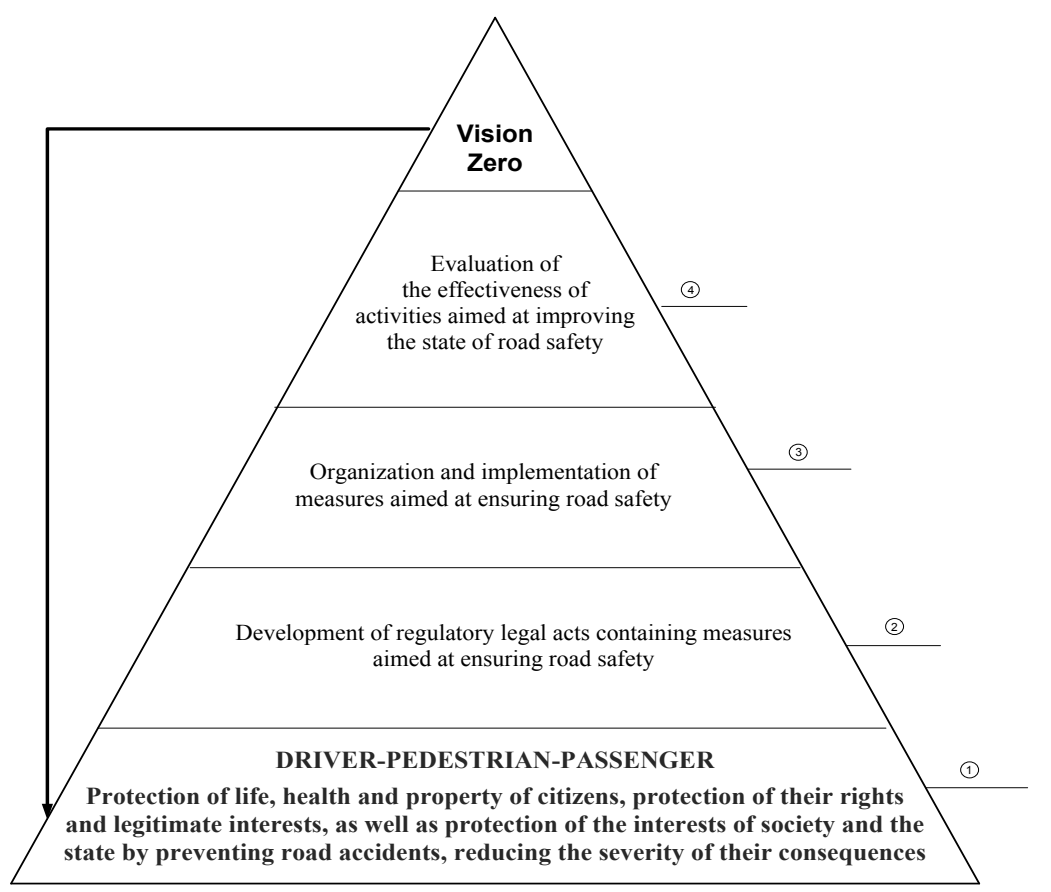

Evaluation indicators: absolute-the number of road accidents, the number of dead and injured, relative - social risk, transport risk, severity of consequences Evaluation principles: economic, systemic, stochastic, social

\begin{tabular}{|c|c|c|}
\hline (3) & \multicolumn{2}{|c|}{$\begin{array}{l}\text { Regulatory legal regulation in the field of passenger and cargo transportation by road. } \\
\text { Technical regulation, supervision and control in the field of road transport. } \\
\text { State policy in the field of road safety and measures aimed at reducing the number of road accidents, deaths and } \\
\text { injuries on roads. } \\
\text { Improving the rules of the road. } \\
\text { Questions of organization of technical inspection of vehicles. } \\
\text { The Ministry of Transport (Federal service for supervision in the sphere of transport, Federal road Agency), } \\
\text { Ministry of Science and Higher Education, Ministry of Health, Ministry of Internal Affairs, } \\
\text { Ministry of Industry and Trade }\end{array}$} \\
\hline & \multicolumn{2}{|r|}{$\begin{array}{c}\text { Resolution of the Government of the Russian Federation from February, 20th, 2006 N } 100 \text { "About the } \\
\text { Federal target program "Increasing traffic safety in 2006-2012 years" } \\
\text { Resolution of the Government of the Russian Federation of } 3 \text { October } 2013 \text { N } 864 \text { "On the Federal } \\
\text { target program "Improving road safety in } 2013 \text { - } 2020 \text { years" } \\
\text { The decree of the RF Government of } 8 \text { January } 2018 \text { N 1-p "On approval of the Strategy of road safety } \\
\text { in the Russian Federation 2018-2024 years» }\end{array}$} \\
\hline & (1) & $\begin{array}{c}\text { Federal Law No. 196-FZ of 10.12.1995 " On Road Safety" } \\
\text { Vienna Convention on Road Traffic, } 1968 \\
\text { The Constitution of the Russian Federation of } 12.12 .1993 \text { as amended on } 01.07 .2020\end{array}$ \\
\hline
\end{tabular}

Fig. 2. Conceptual foundations of road safety theory 
Therefore, the second level of the pyramid will be the development of measures aimed at ensuring road safety. Close attention to the state of transport process safety in the Russian Federation at the state level began to be paid at the beginning of the XXI century. It was then that the first (2006 - 2012) and later the second (2013 - 2020) Federal Targeted Programs aimed at improving road safety were developed.

The vast majority of events contained in the reviewed documents have an organizational or technical nature and are to regulate activities on road transport in the road sector, the implementation of traffic organization, compulsory certification of vehicles, licensing of separate types of activity on motor transport, carrying out of socially-oriented activities in the transport sector; the implementation of Federal state supervision in the field of ensuring road safety.

It is worth noting that at this level, measures are provided for not only the organization of training of drivers of vehicles, but also the training of citizens in the rules and requirements of road safety, which is relevant to all participants in the transport process, i.e. citizens of various administrative and legal status.

These measures are developed in the regulatory legal acts, regulations in the field of road safety and establish the powers and responsibilities of the Government of the Russian Federation, federal executive authorities, executive authorities of the subjects of the Russian Federation and local self-government bodies. The third level of the pyramid reflects the implementation of the measures specified at the second level, as well as the control of the activities of public associations, legal entities and individuals in order to prevent road accidents and reduce the severity of their consequences.

This is a meaningful level in which measures are implemented related to the construction, repair and operation of highways and equipping them with technical means of traffic management, with the improvement of vehicles and the training of drivers for safe participation in the transport process. The implementation of these measures falls within the competence of the Ministry of Transport (Federal Service for Supervision of Transport, Federal Road Agency), the Ministry of Science and Higher Education, the Ministry of Health, the Ministry of Internal Affairs and is distributed among subordinate organizations and institutions.

The fourth level of the pyramid is an assessment of the effectiveness of activities aimed at improving the state of road safety.

The simplest way to evaluate the effectiveness is to compare absolute or relative indicators that objectively reflect the state of accidents in road transport for a certain period of time: the number of road accidents, citizens injured in them in the total number and specifically drivers, violators of traffic rules, the number of people killed in an accident per 10 thousand vehicles (transport risk), the number of people killed in an accident per 100 thousand. population (social risk), the number of deaths per 100 injured in road accidents (severity of consequences), an absolute indicator compared to the indicator of the previous year. $[12,13]$

But, the main principle of performance evaluation is the monetary approach. The principles of consistency and stochasticity of the conditions for their implementation are important and must be taken into account when evaluating the effectiveness of road safety measures. [14, 15]

The assessment of the effectiveness of measures should be carried out from the perspective of not only "economic losses" (transport delays, fuel overruns, wear and damage to vehicles, loss of profit by road users and losses in related industries), but also "social losses", since the top of the pyramid of road safety theory is the indicator of "zero mortality" as a result of road accidents. "Economic losses" have an unambiguous monetary equivalent, while "social losses" affect the fullness of a person or society as a whole (losses 
associated with the death of a person, with his mental and physical health) and their assessment is made indirectly due to the lack of methodological developments in this area.

The Vision Zero program takes into account the principles of "control and separation", "functional harmony"," predictability and simplicity"," striving for limitations " and has been widely understood in the countries of Western Europe and North America.

The transcontinental location of the territory of the Russian Federation, the presence of different geographical zones and climatic conditions, the formation of some republics, autonomous districts and regions on a national basis determines the differentiation in the knowledge of the theoretical foundations of road safety.

With territorial differentiation, taking into account the social, economic and transport indicators of the development of settlements, the effectiveness of measures to prevent road accidents increases significantly.

The presented theory has a conceptual structure and is proposed in the development of the existing theory of traffic management, allows you to understand, explain and predict the state of road safety. This theory assumes the appearance of a certain factor - "zero mortality", which is a consequence of the role of scientific facts and practical knowledge used in the theory of road safety.

The work was performed under the RGNF grant 21-19-00240.

\section{References}

1. World report on the prevention of road accidents / trans. from English-Moscow: Publishing House "All the world", 280 p. (2004)

2. E. Rune, Handbook of road traffic safety / E. Rune, Anne Borger Musen, Truls Vaa. Per. with norv. U. Agopova; edited by prof. V. V. Silyanov, MADI, 746 p. (2001)

3. List of instructions based on the results of the State Council meeting of June 26, 2019 http://kremlin.ru/events/president/transcripts/60825

4. R. S. Akhmadiev, R. N. Minnikhanov Management of the life safety provision system on roads Journal of Advanced Research in Law and Economics. v. 7. No. 2, pp. 193201 (2016)

5. V. A. Ambartsumyan, System analysis of problems of road traffic support: textbook. manual. St. Petersburg: SPbGAU Publishing House, 352 p. (1999)

6. V. N. Baskov, L. Ya. Kozhukhovskaya Criterion base for ensuring the quality and safety of transport processes, Scientific review, No. 12, pp. 387-392 (2013)

7. A. Chubukov, V. Silyanov, V. Kapitanov, O. Monina, U. Brannolte Calculation of traffic capacity of signaled intersections, Transportation Re-search Procedure, pp. 125131 (2017)

8. I.A. Novikov, A.G. Shevtsova, A.E. Borovskoy Research of influence of time of reaction of driver on the calcula-tion of the capacity of the highway, Transport problems, V. 10, Is. 3. Pp. 53-59 (2015)

9. I. A. Novikov, V. M. Vlasov, A. N. Novikov, A. G. Shevtsova, Definition of the perspective scheme of organization of traffic using methods of forecasting and modeling, "International Conference on Mechanical Engineering, Automation and Control Systems 2017, Processing Equipment, Mechanical Engineering Processes and Metals Treatment", pp. 042116-042121 (2018)

10. I. A. Novikov, A. G. Shevtsova, G. A. Bakharev Estimation of dynamics of accidents on the roads of the Russian Federation and measures for its reduction, Technics and technologies of construction, № 4(4), pp. 5-10 (2015)

11. N. I. Matuzov, A.V. Malko Theory of State and law: course of lectures M.: Lawye. p. 189 (2007) 
12. I. E. Ilyina, Techniques for assessing road safety: a review, Transport of the Russian Federation, No. 1(86), pp. 22-25 (2020).

13. E. V. Dinges, Methods of planning and evaluating the effectiveness of measures to improve road safety: monograph, MADI, 140 p. (2016)

14. E. V. Dinges, Ways of improving the system of ensuring road traffic safety (economic aspect) INFORMAVTODOR, Issue 4, pp. 5-37. (1994)

15. V. V. Chvanov, Research of the influence of socio-economic factors and the development of the road network on traffic safety, Nauka i tekhnika $\mathrm{v}$ dorozhnoy otrasli, Dorogi Publishing House, No. 3, pp. 34-38 (2005) 